Nadwa : Jurnal Pendidikan Islam

Vol. 14, No.1 (2020)

Accredited by Ristekdikti based on Decree No. 51/E/KPT/2017

DOI: $10.21580 / \mathrm{nw} \cdot 2020.14 .1 .5672$

\title{
Is Online Learning Accessible During COVID-19 Pandemic? Voices and Experiences of UIN Sunan Kalijaga Students with Disabilities
}

Ro'fah

Center for Disability Services (PLD)

UIN Sunan Kalijaga Yogyakarta Indonesia

rofah@uin-suka.ac.id

\section{Astri Hanjarwati}

Dept. of Sociology, UIN Sunan Kalijaga Yogyakarta Indonesia

astri.hanjarwati@uin-suka.ac.id

\section{Jamil Suprihatiningrum}

PLD, UIN Sunan Kalijaga Yogyakarta

College of Education, Psychology and Social work

Flinders University, South Australia

jamil.suprihatiningrum@flinders.edu.au

\begin{abstract}
The study seeks to examine the voices and experiences of students with disabilities in navigating online learning during the COVID-19. Based on indepth interviews with thirty-four students with various disabilities of UIN Sunan Kalijaga, this study attempts to answer how these students experiencing online learning, what challenges they encounter, and what strategies they are using to navigate this new way of learning. Results show most students prefer conventional face-to-face learning, compared to the online learning one. Students reported various challenges they experienced, the most important of which is the high cost of internet access. Other challenges include the inaccessibility of the e-learning system with respect to the platform of online learning and the learning activities. Students also concerned with the absence of supports that they normally received from the university's disability office (Pusat Layanan Difabel/ PLD). These challenges have encouraged students to seek help from family members, peers, and lecturers.
\end{abstract}

Keywords: COVID-19; online learning; accessibility; students with disabilities; Pusat Layanan Difabel 


\title{
$2 \mid$ Ro'fah, at.all
}

\begin{abstract}
Abstrak
Studi ini berupaya untuk mengevaluasi pendapat dan pengalaman siswa penyandang cacat dalam menavigasi pembelajaran online selama COVID-19. Berdasarkan wawancara mendalam dengan tigapuluh empat mahasiswa dengan berbagai kecacatan di UIN Sunan Kalijaga, penelitian ini mencoba menjawab bagaimana para siswa ini mengalami pembelajaran online, tantangan apa yang mereka hadapi, dan strategi apa yang mereka gunakan untuk menavigasi cara belajar baru ini. Hasil menunjukkan sebagian besar siswa lebih suka pembelajaran tatap muka konvensional, dibandingkan dengan pembelajaran online. Siswa melaporkan berbagai tantangan yang mereka alami, yang terpenting adalah tingginya biaya akses internet. Tantangan lain termasuk tidak dapat diaksesnya sistem e-learning sehubungan dengan platform pembelajaran online dan kegiatan pembelajaran. Siswa juga khawatir dengan tidak adanya dukungan yang biasanya mereka terima dari Pusat Layanan Difabel (PLD) universitas. Tantangan-tantangan ini telah mendorong siswa untuk mencari bantuan dari anggota keluarga, teman sebaya, dan dosen. Kata kunci: COVID-19; pembelajaran online; aksesibilitas; siswa penyandang cacat; Pusat Layanan Difabel
\end{abstract}

\section{Introduction}

People with disabilities are frequently at increased risk during disasters and emergencies. Physical and communication barriers prevent them to provide an effective reaction in crisis circumstances. 1 Also, the marginalization of the people with disabilities, whether structured or not, occurs in all stages of disaster response. Various studies show that people with disabilities are not fully accommodated during the evacuation, at the emergency phase, as well as during the recovery stage. 2 The

1 David Alexander, "Disability and Disaster," in Handbook of Hazards and Disaster Risk Reduction, ed. Ben Wisner, Ilan Kelman, and JC Gaillard (New York: Routledge, 2012), 413-23.

2 Gay J Mc Dougall, "World Disasters Report 2007: Focus on Discrimination," Report Book, World Disaster 2007 (Geneva, CH: Internasional Federation of Red Cross and Crescent Societies, 2007), 
COVID-19 pandemic is a disaster and global health crisis that has a significant impact on all aspects of social life, including education. 3 This pandemic affects $90.2 \%$ of students worldwide, in which 1.57 billion students are absent from school and 191 countries including Indonesia close the schools and change learning methods significantly by imposing learning at home through online learning system.4 The school's closure has brought significant social and economic impacts for all levels of society, especially the vulnerable groups, including students with disabilities. 5 The massive transfer of classrooms to homes presents huge challenges both technically and socially; it enhances social isolation-as schools are a place for social

https://www.ifrc.org/en/publications-and-reports/world-disastersreport/wdr2007/.

3 Maria Nicola et al., "The Socio-Economic Implications of the Coronavirus and COVID-19 Pandemic: A Review," International Journal of Surgery (London, England), April 17, 2020, https://doi.org/10.1016/j.ijsu.2020.04.018; Mohamed H. Taha et al., "Curriculum Delivery in Medical Education during an Emergency: A Guide Based on the Responses to the COVID-19 Pandemic," MedEdPublish 9, no. 1 (April 16, 2020): 1-12, https://doi.org/10.15694/mep.2020.000069.1.

4 Francisco Jonathan de Oliveira Araújo et al., "Impact Of Sars-Cov-2 And Its Reverberation In Global Higher Education And Mental Health," Psychiatry Research 288 (April 12, 2020): 112977, https://doi.org/10.1016/j.psychres.2020.112977; Heini Utunen et al., "Global Reach of an Online COVID-19 Course in Multiple Languages on OpenWHO in the First Quarter of 2020: Analysis of Platform Use Data," Journal of Medical Internet Research 22, no. 4 (27 2020): e19076, https://doi.org/10.2196/19076.

5 Theopania Chavatzia and Megumi Watanabe, "Preparing The Reopening of Schools," Resource Paper, Education Covid-19 Response (Ajuba, Bangkok, Beijing, Hanoi, Mexico, and Santiago: UNESCO International Institute For Educational Planning (IIEP), May 5, 2020), 1-29, https://unesdoc.unesco.org/ark:/48223/pf0000373401. 
interaction-and increases challenges in monitoring and assessing the learning process.

Online learning - that has been applied globally during social distancing - is not a new practice in education. Neither it is a new way of learning for students with disabilities. Numerous studies show that many students with disabilities prefer online learning as it deemed to provide a solution in terms of both accessibility, flexibility and ability to control the learning process. 6 The issue of accessibility of online learning for students with disabilities, however, continues to be questioned.7 Consequently, UNESCO in 2016 published the guidance titled "Open and Distance Learning", in which includes the element of accessibility for people with disabilities. 8

There is a growing body of literature on online learning for students with disabilities. 9 In the context of developing countries such as Indonesia, however, this issue remains under-researched. This paper is intended to fill the gap. It describes the

6 Dr Debanjan Banerjee, "Psychological Preparedness for the COVID19 Pandemic, Perspectives from India," Psychiatry Research 288 (June 2020): 112999, https://doi.org/10.1016/j.psychres.2020.112999.

7 Nancy Hollins and Alan R. Foley, "The Experiences of Students with Learning Disabilities in a Higher Education Virtual Campus," Educational Technology Research and Development 61, no. 4 (August 1, 2013): 607-24, https://doi.org/10.1007/s11423-013-9302-9.

8 Chambers Dianne, Varoglu Zeynep, and Kasinskaite-Buddeberg Irmgarda, Learning for All: Guidelines on the Inclusion of Learners with Disabilities in Open and Distance Learning (France: UNESCO Publishing, 2016).

9 Mary F. Rice and Bryan Dykman, "The Emerging Research Base on Online Learning and Students with Disabilities," in Handbook of Research on K-12 Online and Blended Learning, ed. Richard E. Ferdig and Kathryn Kennedy (Pittsburgh, PA: Carnegie Mellon University, 2018), https://doi.org/10.1184/R1/6686813.v1. 
experiences of students with disabilities in conducting online learning. The main questions to address what is the perspective of a student on online learning, what challenges and barriers do they experience and what strategies they are using to overcome the barriers.

\section{The COVID-19 Pandemic and Its Implications for}

\section{Education}

As a result of the COVID-19 Pandemic, WHO established the Public Health Emergency of International Concern (PHEIC) on 30 January 2020.10 WHO recorded 3,349,786 positive confirmed cases worldwide with 238,628 deaths on 3 May 2020. The rapid spread of COVID-19 forced all affected countries to adopt social and physical distancing policies to fight against the spread of the virus.11 In Indonesia, this policy is known as Work from Home (WFH) and School from Home (SFH). Related to $\mathrm{SFH}$, various strategies carried out by countries in the world in facing the COVID-19 Pandemic, namely:12 (1) Increase

10 Y. Yuliana, "Corona virus diseases (Covid-19): Sebuah tinjauan literatur," Wellness And Healthy Magazine 2, no. 1 (March 6, 2020): 187192-192.

11 Hiba Hafiz et al., "Regulating in Pandemic: Evaluating Economic and Financial Policy Responses to the Coronavirus Crisis," SSRN Scholarly Paper, Update To Include Discussion of H.R. (Rochester, NY: Social Science Research Network Boston Collage Law School., March 17, 2020), https://doi.org/10.2139/ssrn.3555980; Lendel Narine and Cristian Meier, "Responding In a Time of Crisis: Assessing Extension Efforts During COVID-19," Advancements in Agricultural Development 1, no. 2 (April 17, 2020): 12-23, https://doi.org/10.37433/aad.v1i2.35.

12 Kaliope Azzi-Huck and Tigran Shmis, "Managing the Impact of COVID-19 on Education Systems Around the World: How Countries Are Preparing, Poping, and Planning for Recovery," Opini, Published on Education for Global Development, March 18, 2020, 


\section{6 |Ro'fah, at.all}

preparedness while keeping schools open. This is involving the enforcement and supporting of preventive actions in schools (Afghanistan); establishing protocols for handling diseases and potential cases in schools (Egypt, Russia, Belarus); using education system infrastructure and human resources to deal with the spread of infection in the community (Liberia and Sierra Leone); and limiting physical contact by reducing social and extra-curricular activities (Singapore, Russia). (2). Close school selectively. The government is selecting the local school's closure (in certain areas) as a preventive measure (India, Brazil, India, Canada, and Australia). (3). Close the school nationally. This option is most widely applied by affected countries, based on concerns that school-age children can be carriers of the virus to vulnerable family members, such as parents.

This study applied a qualitative descriptive approach with in-depth interviews as the main method for data collection. Thirty-four students with disabilities (see Figure 1) in UIN Sunan Kalijaga, who received services and supports from the Center for Disability Services (PLD) were selected purposively to be involved in the preliminary research. Eight of them are selected for further interviews to get an in-depth picture of the experiences and barriers experienced by students with disabilities in online learning. Following the COVID-19 protocol, interviews were conducted entirely by phone and WhatsApp (WA) conversation.

In the preliminary study, students were given a questionnaire to summarize quantitative data about the types of their disabilities, their preferences of learning systems and the platform used for online learning.

https://blogs.worldbank.org/education/managing-impact-covid-19-educationsystems-around-world-how-countries-are-preparing. 


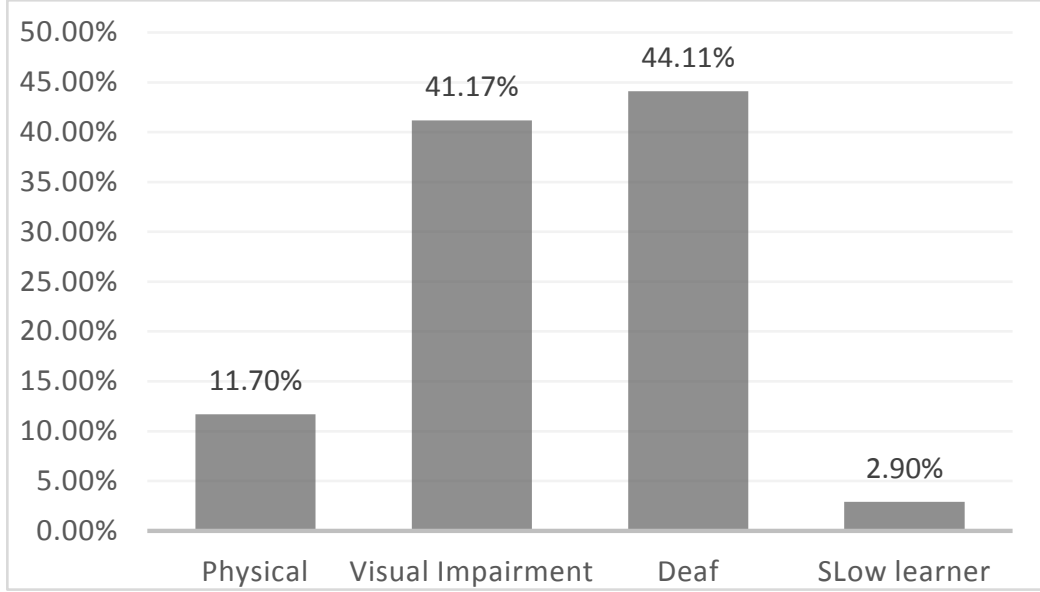

Figure 1. Percentage of distribution of respondents by type of disability

Data from the questionnaire were analyzed quantitatively using SPSS software version 25, to classify data based on respondents' answers. Data from in-depth interviews were analyzed qualitatively by coding the interview transcripts and emerged themes based on respondents' answers. These themes are determined in two ways, i.e. deductively (through literature reviews) and inductively (based on findings). The three themes revealed are preferences of the learning system and the apps used for online learning, barriers to online learning, and students' efforts to overcome the barriers. 
8 | Ro'fah, at.all

\section{Learning and distance education resources to reduce learning loss}

This policy is adopted by China; they established a "Suspending Classes without Stopping Learning" policy,13 as well as Italy, France, Germany, and Saudi Arabia. These countries implement a fully online learning. Vietnam and Mongolia use cell phones and TV broadcasts as online learning media. Lebanon treats homework as a form of learning at home. In Bulgaria, more than 800,000 accounts have been created for all teachers and parents, publishers have been mobilized to open digital textbooks and learning material for grades 1 to 10, and two national TV broadcast educational channels.

The School from Home policy adopted by Indonesian government is another example the use of online and distant learning. Cell phone are used widely and after some weeks, governments decide to use the nation; television station, TVRI, as media of learning, aimed to minimize the problem of internet access. To a certain extent, Indonesian government has been working with telecommunication industries to provide a free access to educational website in order to solve the high internet cost.

According to Saavedra (2020), many educations ministries concern that online learning only reaches children from prosperous families.14 Therefore, he offers several suggestions:

13 Wunong Zhang et al., "Suspending Classes Without Stopping Learning: China's Education Emergency Management Policy in the COVID19 Outbreak," Journal of Risk and Financial Management 13, no. 3 (March 2020): 55, https://doi.org/10.3390/jrfm13030055.

14 Jaime Saavedra, "Educational Challenges and Oportunities of the Coronavirus (COVID-19) Pandemic," Opini, Published on Education for Global Development, March 30 , 2020 , https://blogs.worldbank.org/education/educational-challenges-andopportunities-covid-19-pandemic. 
each country adjusts to existing infrastructure and applies online media to ensure that lesson plans, videos, tutorials, and other resources are available for access; utilizes podcasts and other resources that require less data usage; working with telecommunications companies to implement a zero cost policy can also facilitate learning material to be downloaded on smartphones, which are likely to be owned by more students; use radio and TV as media for delivering learning content; use social networks like WA or SMS to correspond with students, teachers, and parents.

Four priorities as changes in the school system during the COVID-19 Pandemic period, i.e.: protecting the health and safety of students, staff and the community; maximizing student learning and development; supporting teachers and staff, and building safe operational and financial foundations.15 Six elements that must be managed related to the online learning transition during the COVID-19 Pandemic, which is "community care, clear communications, clarified expectations, constructive alignment, a community of practice, ability to compromise and adapt and continuity planning".16 To make the smooth transition to online learning it needs five things, i.e. not turning all material into video, not relying on video conferencing technology such as zoom for learning, giving students initiatives to learn independently and providing feedback, often asking students' learning progress without

15 Jake Bryant et al., "School-System Priorities in the Age of Coronavirus," Opini, K-12 Education and the Coronavirus, April 21, 2020, https://www.mckinsey.com/industries/public-sector/our-insights/schoolsystem-priorities-in-the-age-of-coronavirus.

16 Nalini Pather et al., "Forced Disruption of Anatomy Education in Australia and New Zealand: An Acute Response to the Covid-19 Pandemic," Anatomical

Sciences

Education,

2020 ,

$1-14$, https://doi.org/10.1002/ase.1968. 
having to face-to-face online, and identifying the supports that can be offered to students who have learning difficulties.17

\section{Online Learning for Students with Disabilities}

Online learning is one part of Online and Distance Learning (ODL), an umbrella term that refer to a variety of learning practices: e-learning, distance learning, learning through correspondence, flexible learning, and Massive Online Course Movement/MOCM.18 The core characters of ODL with all its variants are four, namely: the separation of teachers and students both in time and space, the use of technology, learning experiences that are more individual and include two-way communication and wider networks. 19

Many believe that ODL has been increasingly adopted by many countries across the globe as it being regarded as a practical way to increase access to higher education.20 It is considered to offer privacy, flexibility, comfort, and its ability to accommodate the needs of diverse learners including those with disabilities.21 Online learning is also considered cost-effective; it

17 Virginia Gewin, "Five Tips for Moving Teaching Online as COVID19 Takes Hold," Nature 580, no. 7802 (March 24, 2020): 295-96, https://doi.org/10.1038/d41586-020-00896-7.

18 Chambers Dianne, Varoglu Zeynep, and Kasinskaite-Buddeberg Irmgarda, Learning for All.

19 Chambers Dianne, Varoglu Zeynep, and Kasinskaite-Buddeberg Irmgarda.

20 Cindy Davi, "There to Stay: Remote Learning Is Poised to Remain a Prominent Fixture of Higher Education," News, systemscontractor, 2020, https://www.avnetwork.com/features/bus-learning-tech-team-discusses-theirmove-to-virtual-classrooms.

21 Guanghai Wang et al., "Mitigate the Effects of Home Confinement on Children During the COVID-19 Outbreak," The Lancet 395, no. 10228 (March 21, 2020): 945-47, https://doi.org/10.1016/S0140-6736(20)30547-X; Andrew I. Hashey and Skip Stahl, "Making Online Learning Accessible for 
reduces the living cost, transportation and housing; it also deemed as an effective solution for educational institution with a broad geographical distribution of students.22 Other benefits noted in the study are it solves the issue of space limitation of the university as well as crowded classrooms;23 and it can improve the quality of learning. 24

The trend of ODL can be seen from the US experience. In the period of 2012 - 2017 there was an increase in the number of students taking full online education from $12.6 \%$ to $15.7 \%$, while those taking one or more online courses reached $18 \%$ in 2017, up almost 5\% compared to 2012.25

In Indonesia, the Open University (Universitas Terbuka) is known as a pioneer of online learning, but in the past few years some universities such as UI, ITB and private universities such as Binus and Mercu Buana, Sahid University, Taradina

Students With Disabilities:," TEACHING Exceptional Children 45, no. 5 (April 11, 2014): 70-78, https://doi.org/10.1177/0040059914528329.

22 Christy G. Keeler and Mark Horney, "Online Course Designs: Are Special Needs Being Met?," American Journal of Distance Education 21, no. 2 (June 15, 2007): 61-75, https://doi.org/10.1080/08923640701298985.

23 Robert Connor Chick et al., "Using Technology to Maintain the Education of Residents During the COVID-19 Pandemic," Journal of Surgical Education, April 3, 2020, https://doi.org/10.1016/j.jsurg.2020.03.018.

24 Rachel Grieve et al., "Face-to-Face or Facebook: Can Social Connectedness Be Derived Online?," Computers in Human Behavior 29, no. 3 (May 1, 2013): 604-9, https://doi.org/10.1016/j.chb.2012.11.017.

25 Jianxia Du, Byron Havard, and Heng Li, "Dynamic Online Discussion: Task-oriented Interaction for Deep Learning," Educational Media International 42, no. 3 (September 1, 2005): 207-18, https://doi.org/10.1080/09523980500161221. 
University, Al Azhar University, Al Syafiiyah University started to offer online systems for certain courses and programs.26

Regarding people with disabilities, numerous studies suggested confirmed that online learning is an effective solution to increase the participation of students with disabilities in higher education.27 Other studies noted the benefits of online learning for students with disabilities both in terms of information accessibility and mobility.28 In Burdette's research on primary to secondary education in US, the preference of students with disabilities for online learning is triggered by reasons of flexibility, quality of learning and affordable expenses.29 Harvey, Greer, Basham, and Hu's30 research found that students with disabilities - and their parents - reported of being satisfied with the online system as it was significantly boosted their learning success.

26 Raian Ali et al., "Social Adaptation: When Software Gives Users a Voice" (ENASE 2012: 7th International Conference Evaluation of Novel Approaches to Software Engineering, Wroclaw, Poland, 2012), http://www.enase.org/?y=2012.

27 Karen Kear et al., "Social Technologies for Online Learning: Theoretical and Contextual Issues," Open Learning: The Journal of Open, Distance and e-Learning 31, no. 1 (January 2, 2016): 42-53, https://doi.org/10.1080/02680513.2016.1140570.

28 Andrew I. Hashey and Stahl, "Making Online Learning Accessible for Students With Disabilities."

29 Jake Bryant et al., "School-System Priorities in the Age of Coronavirus."

30 Danna Harvey et al., "From the Student Perspective: Experiences of Middle and High School Students in Online Learning," American Journal of Distance Education 28, no. 1 (January 2, 2014): 14-26, https://doi.org/10.1080/08923647.2014.868739. 
In a more detailed, Holloway and Foley31 listed the pros and cons of online learning for students with disabilities. Accessibility is a significant aspect to be highlighted in online learning.32 For those with physical disabilities - and mobility constraint, online learning addresses the problems of inaccessible transportation, campus environment and learning spaces. Meanwhile, students with cerebral palsy, muscular dystrophy or Lou Gehrig's disease who have difficulty in controlling hand or foot movements, they benefited from a wide array of assistive technology widely used in online learning such as voice-activated programs, speech-recognition, screen reader, Dragon Naturally Speaking or even eye-tracking technologies that allow them to access learning activities. For those with mental and cognitive conditions, including that of Asperger's Syndrome, Autism, and anxiety disorders, Holloway and Foley further noted, online learning help them to reduces anxiety and social pressure from a crowded campus and classroom atmosphere. The flexibility of time and schedules in online learning is also considered very accommodating for students with mental and psychological disorders as it allows them to learn in their own pace. 33

It should be noted, however, that accessibility is not naturally embedded in online learning and hence it is not

31 Jan Hollpway and Chris Foley, "Pros, Cons of Online Education for Students With Disabilities Be Sure Consider Technical and Personal Needs Befor Diving Into Online Learning," Opini, Education, May 18, 2018, https://www.usnews.com/education/online-learning-lessons/articles/2018-0518/pros-cons-of-online-education-for-students-with-disabilities.

32 William E. Halal, "The Power of Online Learning Systems.," Opini, The Future of The Future, 2006, https://www.kmworld.com/Articles/Columns/The-Future-of-the-Future/TheFuture-of-the-Future-The-power-of-online-learning-systems-16909.aspx.

33 William E. Halal. 
automatically accessible for students with disabilities. Many online courses were not designed by considering accessibility aspects.34 In other words whether or not the digital world is accessible would be determined by its developer.35 For this reason, online learning accessibility can only occur when it deliberately built by considering the needs of learners in all aspects: the content, learning strategy and process, the choice of technology and the capacity of human resource.36

Some research noted the technical barriers faced by students with disabilities in accessing technology. For example documented several barriers that include e accessibility of websites and learning management systems, the accessibility of digital audio and video content and alternatives, inflexible time limits built into online exams, the accessibility of PowerPoint presentations, and also course material in inaccessible PDF formats and the lack of access to assistive technologies.37 Inaccessible chat rooms and screen readers for students with disabilities.38 This finding is supported by other findings that

34 Jodi B. Roberts, Laura A. Crittenden, and Jason C. Crittenden, "Students with Disabilities and Online Learning: A Cross-Institutional Study of Perceived Satisfaction with Accessibility Compliance and Services," The Internet and Higher Education 14, no. 4 (September 1, 2011): 242-50, https://doi.org/10.1016/j.iheduc.2011.05.004.

35 Herbert Jaeger, "The"'Echo State" Approach to Analysing and Training Recurrent Neural Networks," Paper Working, Fraunhofer Institute for Autonomous Intelligent System (German: German Nasional research Center For Information Technology, 2010).

36 Lendel Narine and Cristian Meier, "Responding in a Time of Crisis."

37 Catherine S. Fichten et al., "Disabilities and E-Learning Problems and Solutions: An Exploratory Study," Educational Technology \& Society 12, no. 4 (2009): 241-56.

38 Lin Y. Muilenburg and Zane L. Berge, "Student Barriers to Online Learning: A Factor Analytic Study," Distance Education 26, no. 1 (January 1, 2005): 29-48, https://doi.org/10.1080/01587910500081269. 
identify several other obstacles that students might face in online learning.39 First, online learning requires students to be able to control and navigate technology and learning content independently, and this may not be possible for some students with certain disabilities. Second, assistive technology-either software or hardware-is not always accessible.40 Students with hearing can access not all electronic text formats and visual impairment, either because of the size and type of font or the type of file is not readable by the screen reader. There are also images and shapes in the learning material that can trigger seizures for students who have epilepsy or other types of disabilities that are sensitive to certain shapes and images. For students with hearing impairment, the level of accuracy of audio learning material is not always appropriate although it is equipped with on time subtitles (caption), because of the gap between the speed of sound and its caption. Third, electronic materials with various formats, both audio and video often require high bandwidth and a high-quality internet network.

These circumstances encourage several institutions other than UNESCO, to ensure accessibility in online learning. One of them is the Web Accessibility Initiative (WAI), which builds an information portal that explains accessibility principles on websites to improve information accessibility both in general and in the context of ODL.

\section{Students’ Preferences on Learning System}

39 Timothy Morse, "Ensuring Equality of Educational Opportunity in the Digital Age," Education and Urban Society 36 (May 1, 2004): 266-79, https://doi.org/10.1177/0013124504264103.

40 Lorrayne Porciuncula and Sam Paltridge, "Bridging the Rural Digital Divide," OECD Digiatal Economy Paper, no. 265 (February 23, 2018): 171, https://doi.org/10.1787/852bd3b9-en. 
The results of the questionnaire regarding learning system preferences showed that $79.41 \%$ of students selected face-toface instruction while $20.50 \%$ preferred online systems. Data segregation based on the type of disabilities are presented in Figure 2.

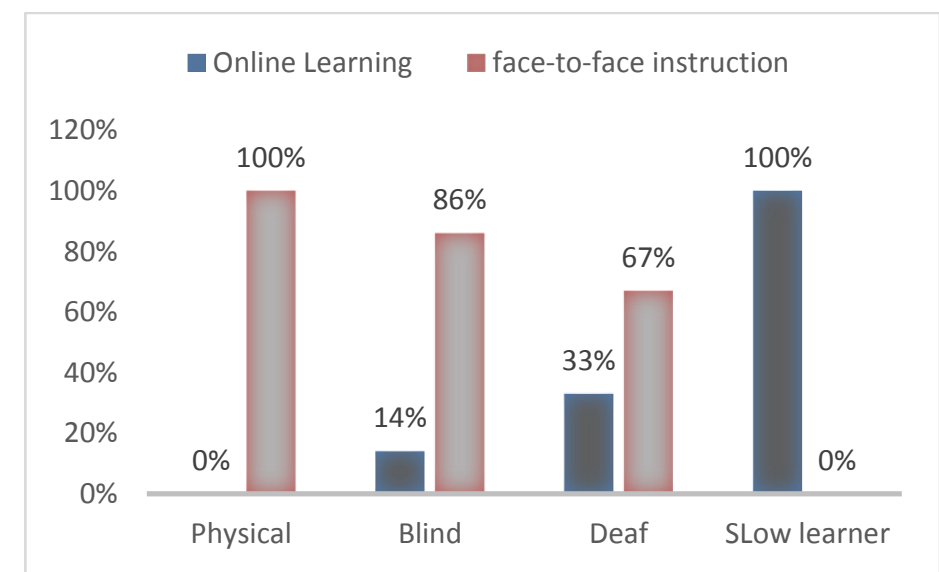

Figure 2. Preference of learning system based on type of disability

Most students argued that face-to-face instruction provides an opportunity for students to better engage and, thus, understand the learning material. In contrast, online learning requires students to be able to study independently. The loss of face-to-face interaction and the reliance of the online platform on written communication create significant barriers for student with disabilities in understanding the material. Adding to this is the difficulty that student face in finding the appropriate references for the assignment. Andi, a student with visual impairment said:

The initial online learning applied by my lecturer, it was not the delivery of material but the assignment. The lecturer only gave us a modest introduction and then 
burdened us with assignments. I could not understand the material without explanation. 41

Some other students confirmed Andi's statement regarding the high volume of assignment that students need to complete and the difficulty in understanding instructions. For student with visual impairment in particular written-based learning process - through WA message - is considered to be extremely timeconsuming; they need much longer time to read the written messages, and therefore unable to participate in the discussion.

A more important reason behind students' preference on traditional learning is the availability of volunteers (peer support). Since 2007, UIN Sunan Kalijaga has been providing support for its student with disabilities through the Center for Disability Service (Pusat Layanan Difabel/PLD. The center provides assistance to students on daily basis to ensure the accessibility of learning process. There is a wide array of services available ranging from note taker and sign language interpreter for students with hearing impairment to assistive technologies. While PLD is an official unit funded by the university fund, it heavily relies on students volunteer that provide assistance for their peer with disabilities in their academic and social life.

Reno, another student with visually impaired said: To be honest, I am more comfortable with face-to-face learning, because it is easy to meet the lecturer and my classmates. I also could ask support from PLD to provide me a volunteer; it will be easier for me to ask questions, discussions, etc. PLD volunteers help me a lot, so I could easily understand (the material). 42

41 Andi, April 17, 2020.

42 Reno, April 17, 2020. 
Reno's statement underlines the important role that PLD's supports has been playing on the daily life of student's learning.

Twenty percent of students who preferred online learning underlines accessibility as the main reason. This cohort consists of students with hearing impairment who benefited from the written based learning. For students with physical disabilities, online learning diminishes the barriers of mobility that they daily encounter.

\section{Platform Used for Online Learning}

UIN Sunan Kalijaga has an e-learning system integrated in the university's academic system (SIA) since 2013, that is called E-learning. During the online learning policy, E-learning is suggested as the main platform. However, soon after the implementation of online learning policy, issues concerning the cost of internet access and practicality of E-learning start to be voiced by students. In the normal situation, students use free internet access provided by university, however it requires students to be physically present in the university complex. As such, the online learning forces student to spend additional budget to buy data, and therefore finding an affordable and easy way to access platform become the main concern.

The questionnaire showed that during the online learning, university's E-learning was used by $26.08 \%$ of lecturers, far below the use of the WA that reached $43.47 \%$ as shown in Figure 3. This indicated that most students and lecturers find WA as an effective option. Another platform used include zoom, email, and telegram and google classroom. Most of the class however did not use a single platform instead the majority of lecturers use several platforms simultaneously. Sandra, a student in wheel chair mentioned. 
There are 3 apps used by lecturers (web ICT, google classroom, and WA groups), in which each of them has a different function. Web ICT serves to report the attendance for students, to share material links, and assignment links from the lecturers. Google classroom was functioned to collect tasks that have been done and see the details of shared tasks. Moreover, the WA group makes to ask questions that are not yet understood from the material provided with Sandra. 43

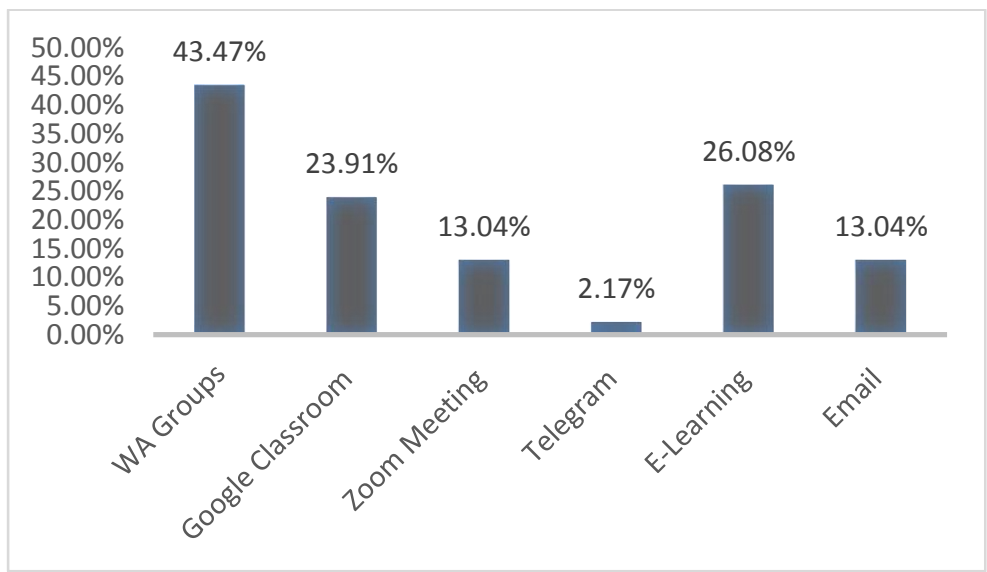

Figure 3. The Application used for online learning

The high rate usage of WA apps in the online learning process seems to be related to the widespread use of this apps among students and lecturers in their daily communication. From further interviews, students claimed that WA is a lightweight app that do not require a big amount of data and therefore affordable, and it can be easily accessed even in a poor or weak internet connection. Other platform such as E-learning, google classroom, and zoom-despite it offers more features and room for interactive communication-it consumes

43 Sandara, April 15, 2020. 
significant amount of data and a stable internet network. During the online learning practice, access to internet becomes even more important because most students have returned to their hometown, where internet network is not even available.

My friends and I like WA because it's cheap. Zoom is expensive because it requires huge data. The lecturer also agreed to use WA to support online learning.44

In addition to Nisa, Ridho, a student with disabilities claimed a similar way:

The cheapest is WA because it needs small data. We didn't need a huge quota to only download the lecturer MP3, and this is still economical. The only drawback is that I sometimes missed the conversation because hundreds of messages popped up on my screen where the ability of the screen reader in my phone is very limited.45 Even although WA is the most preferred apps for students and lecturers, one student with visual impairment admitted that zoom, WebEx, and video meeting offer more accessibility and provide much more interactive learning environment necessary for better students' engagement with the learning process. involving verbal communication with the lecturer were

If I have to choose, I prefer to zoom. It's much more helpful and interactive for the blind. The problem is it consumes huge data and the network connection is sometimes poor. If the campus provides free data we will be very happy. 46

These finding highlights that accessibility of online learning need to be sacrificed for affordability. While WA offers a more limited feature, it is more affordable for students.

44 Nisa, April 16, 2020.

45 Ridho, April 15, 2020.

46 Anton, April 27, 2020. 


\section{Barriers to Online Learning}

The policy of online learning in the context of COVID-19 should be seen as university respond to an unexpected-crisis situation. It is not a policy that developed based on deliberate planning and adequate resources. It as a solution to ensure that students continue to enjoy their right over a quality education amidst disaster situation. As stated earlier, feasibility, affordability and practicality become the main consideration for its implementation at the cost of accessibility for students with disabilities. As a result, students posed challenges and barriers has created Therefore, there are various obstacles faced by students with disabilities when doing online learning.

1. Technical Barriers

The main barrier reported by all respondents is the cost of online learning. Online learning has become additional expenses for most student with disabilities. It worth noting that many of these students are coming from economically disadvantageous family, with very limited or no financial support from their parents. Ridho, Andri, and Beti for instance supporting themselves by selling snack that they distribute in and off the campus. During the pandemic, they need to stop their business and loss their income.

UIN Sunan Kalijaga, in collaboration with various telecommunication companies, has been trying to provide free internet access. Yet, the access is limited to the university's website including E-learning. In short, online learning is an expensive process and is not always affordable for the majority of students.

This condition is exacerbated by - as discussed previouslythe issue internet connection for students located in remote areas. Due to the poor network, students experience problems 
accessing class either particularly when they are delivered through "heavy" platform such as zoom and google classroom. Ridho, the student with visual impairment stated:

I was less able to interact with the lecturer when he gave online lectures on the zoom. The internet connection went up and down and the microphone button for audio message in the WA sometimes difficult to use. There is time when could not use the microphone, my voice was not reached by the lecturer and other students. 47

2. Barriers Related to Disability

There are several barriers experienced by students with disabilities that are specifically related to their disabilities. For students with visual impairment, accessing written information - that is very dominantly used in online lectures - turn to be a significant barrier. These students admitted that it hard for them to read dozens or even hundreds of messages during the class interaction, and as result they missed their chance for meaningful participation. Another barrier they face is inaccessibility of learning material. While all student with visual impairment is familiar with the screen reader and use it on daily basis, but some type of file remains inaccessible both in online or face to face lesson.

On the other hand, for Deaf students and those with certain degree of hearing impairment written communication is one of their main modes of the communication beside sign language. Therefore, text messaging and other written based interaction during online classes give them significant benefit. Yet it is not short challenges. Some lectures-in variety of degree - use more voice recordings in the WA

47 Ridho, April 21, 2020. 
instead of written texts. Some others also use information on YouTube and video recording to deliver the lecture. In those cases, the information is completely inaccessible for Deaf student, particularly when caption and subtitle are not available. In addition, some assignments require students to give audio presentations that would not be possible without the presence of a sign language interpreter. Rani, the student with hearing impairment said:

In a particular course, I was asked to memorize and read texts, I made a video including the audio, but it was hard for me to produce a sound when I memorized the same text. I can make clear voices but it's hard just reading texts. 48

Careful examination of these barriers indicated the limited knowledge and awareness of the lecturer concerning the accessibility of technology and online learning for of students with disabilities.

3. Student Efforts to Overcome Obstacles

The barriers experienced by students with disabilities encourage some of them to find solutions, one of which is communicating these barriers to the lecturer and request modification. Some students with hearing impairment reported that upon communication, many lecturers provide modification in term of material, assignments, and learning methods. In Nina experience demonstrate this:

My lecturer gave a video that did not have the text. I was confused, and then I sent a WA message and told her that I am Deaf. Alhamdulillah she give a very warm respond and sent me video with the caption. 49

48 Rani, April 16, 2020.

49 Nina, April 18, 2020. 
In addition to communicating with lecture, students are also seeking assistance to family members to navigate the accessibility of class and assignment. Dini, other student with hearing impairment, told the authors her experience. In one of her assignment, Nina is expected to submit a video presentation. After disclosing her disability to the lecturer, Dini is allowed to submit a video in sign language. To make sure her lecturer understands what she is saying, she asked her brother to provide a voice translator for the video. Dini responded:

In a topic of advertising presentation techniques, I was asked to make a video with sign language contained a voice translation. I asked my brother to help fill out the sound in my video. This task was easy for me to do.50

For students with visual impairment, lecturer's support is provided through a modification to the learning method, i.e.: providing material that accessible by a screen reader. Ask privately (via WA) to students about material that is not yet understood; assist students if they are unable to follow the discussion in the WA group. As revealed by Beti:

At the beginning of my online lecture, my difficulty was the material. I could not read, then I communicated this issue to my lecturer. Fortunately, the lecturer sent the material to me and I was able to read it. 51

Aside from Beti, Ridho a visually impaired student also faced difficulties with online learning and could not follow the flow of discussion in the group, as stated in the following interview:

The most difficult in online learning is to follow the discussion at WAG. ... I could read the messages, and

50 Dini, April 18, 2020.

51 Beti, April 26, 2020. 
the most important message from the lecturer was gone. Finally, I sent a WA message to the lecturer and he offered me that was fine to not participate in the discussion. I asked to read the material and if I found difficulties, I should message him. 52

\section{Discussion Learning in UIN Sunan Kalijaga with Students Disabilities.}

The findings of this study in several aspects reaffirm previous research on online learning for students with disabilities and the readiness of higher education institution in responding to the needs of students with disabilities.

First, the preference of students on conventional face-to-face learning methods is linked to the various barriers that the student faced in online learning. As a crisis response, the online learning policy adopted by UIN Sunan Kalijaga, as in other universities, is not necessarily equipped with adequate technology and skilled human resources in selecting, operating and navigating the technology. This is with several other studies that highlight the discrepancies between developing and developed countries in term of technology and infrastructure.53 Developed countries are better equipped than developing and poor countries in transforming to learning online responding to crisis of the COVID-99 Pandemic.54 Those authors strongly underline that access to internet and technology, including the gadget, is one of the main constrain for online learning, besides books and

52 Ridho, April 29, 2020.

53 Kaliope Azzi-Huck and Tigran Shmis, "Managing the Impact of COVID-19 on Education Systems Around the World."

${ }_{54}$ Kaliope Azzi-Huck and Tigran Shmis; Zhang et al., "Suspending Classes Without Stopping Learning." 
supportive parents.55 There are ambiguities and disagreements about online learning, including the work-load that teachers and students need to do for the learning process, what are the appropriate learning settings to select as well as what are its implications for educational equality.56 The authors suggest further that technical obstacles such as weak infrastructure, unskilled teaching staff and student's family situation remain to be crucial obstacles of online learning. 57

Many studies cited in the earlier part of this article agree that that online learning promise significant benefit for students with disabilities for various reasons: accessibility, affordability and autonomy. Yet, the challenges are equally prominent as Hunt - that students with disabilities need a choice to learn successfully from home but not all of them have access to reliable internet tools or services.58 The option of platform used for online learning in this study confirms assessment that during the COVID-19 Pandemic, lecturers and students need to agree on flexible learning settings; by building communication between students with disabilities, lecturers and families about their learning needs.59

The choice of platform and application for online learning in this study is in line with the suggestion of Wood60 that during

55 Jaime Saavedra, "Educational Challenges and Oportunities of the Coronavirus (COVID-19) Pandemic."

${ }_{56}$ Chenghu Zhou et al., "COVID-19: Challenges to GIS with Big Data," Geography and Sustainability 1, no. 1 (March 1, 2020): 77-87, https://doi.org/10.1016/j.geosus.2020.03.005.

57 Zhang et al., "Suspending Classes Without Stopping Learning."

58 Sarah Wood, "How Colleges Can Support Students With Disabilities During Remote Learning," News, Diverse Issues In Higher Education, April 13, 2020, https://diverseeducation.com/article/172812/.

59 Sarah Wood.

60 Sarah Wood. 
the COVID-19 Pandemic, lecturers should use technology and digital materials that are familiar with students with disabilities. The findings of this study also support the study of Kear, Jones, Holden, and Curcher61 which said that in the learning process, there are elements of sociology that work, where social technology (in this study context is WA) can create a learning community because it can facilitate communication between lecturers and students in shared online spaces.

Second, the barriers encountered by students with disabilities in online learning can be classified into two, the common technical barriers experienced by student in general, and those that specifically related to disability. The Students' narratives demonstrated that former challenge outweigh the later. They concern more with cost of internet access than with the accessibility of online learning for them. Again, this confirmed Azzi-Huck and Shmis;62 Paxson;63 studies that online learning requires a quality internet network and this cannot be experienced by all students both for economic reasons (not having access to Wi-Fi or limited credit) or geographical (living in areas that have limited internet access) or both. As reported by Porciuncula and Paltridge, 64 countries that are members of the Organization for Economic Co-operation and Development (OEDC) - including Indonesia - have extreme gaps in terms of

61 Karen Kear et al., "Social Technologies for Online Learning."

62 Kaliope Azzi-Huck and Tigran Shmis, "Managing the Impact of COVID-19 on Education Systems Around the World."

63 Christina Paxson, "College Campuses Must Reopen in the Fall. Here's How We Do It.," The New York Times, April 26, 2020, sec. Opinion, https://www.nytimes.com/2020/04/26/opinion/coronavirus-collegesuniversities.html. Divide."

${ }_{64}$ Lorrayne Porciuncula and Sam Paltridge, "Bridging the Rural Digital 
access to broadband or internet networks between urban and rural areas.

In short, more important to underline is the phenomenon of online learning that occurred in Indonesia during the Pandemic COVID-19 emphasizes the disparity and educational inequality between students with strong socio-economic backgrounds and the weak; and between educational institutions with good resources and technology with those not. The findings of this study support studies that were conducted by several researchers that the shift to online learning65 including the Open Educational Resources (OER) movement66 at the higher education level has a significant influence especially in terms of access and access to quality. Aside from inequality of access, there is also other evidence that states that the use of digital technology in education is not a just democratic activity as often described.67 Hill and Lawton68 said that online learning is not a promising option for developing countries. According to Warschauer and Matuchniak69 a high gap between home access to digital media and inequality in the use and results of technology still occurs in

65 Neil Selwyn and Keri Facer, "The Sociology of Education and Digital Technology: Past, Present and Future," Oxford Review of Education 40, no. 4 (July 4, 2014): 482-96, https://doi.org/10.1080/03054985.2014.933005.

66 Christopher Hill and William Lawton, "Universities, the Digital Divide and Global Inequality," Journal of Higher Education Policy and Management 40, no. 6 (November 2, 2018): 598-610, https://doi.org/10.1080/1360080X.2018.1531211.

67 Timothy Morse, "Ensuring Equality of Educational Opportunity in the Digital Age."

68 Jack R Fraenkel and Norman E Wallen, How to Design and Evaluate Research In Education (New York: McGraw Hill, 2003).

69 Mark Warschauer and Tina Matuchniak, "New Technology and Digital Worlds: Analyzing Evidence of Equity in Access, Use, and Outcomes:," Review of Research in Education 34, no. 1 (March 1, 2010), https://doi.org/10.3102/0091732X09349791. 
the US; presumably even more in developing countries like Indonesia.

Related to disabilities, this study confirms the results of previous studies70 such as Fichten et al,71 Van den Bunt-Khokuis and Bolger72 analysis that has been presented in the earlier part of this writing. The platforms, technologies, and apps used in online learning are not yet fully accessible for students with disabilities, especially those with sensory impairment (vision and hearing). Audio learning material, for example, cannot be accessed by students with hearing impairment without captions or subtitles, while at the same time written information that dominates the online learning process either through WA, elearning, or other apps is not fully accessible through screen readers by students with visual impairment. Although in general the latest technology offers accessibility, to date both the university and PLD as a service unit for students with disabilities have not paid serious attention to ensuring technological accessibility for students with disabilities especially for online learning. Information about the principles of accessibility that have been regulated by several world institutions such as WAI has not been applied.

Third, as Foley and Holloway asserted, online learning requires student independence to navigate access and learning material.73 In the context of students with disabilities at UIN Sunan Kalijaga, as in other universities in Indonesia, navigation here must also be translated with the ability of students to seek

70 Fichten et al., "Disabilities and E-Learning Problems and Solutions."

71 Fichten et al.

72 Lin Y. Muilenburg and Zane L. Berge, "Student Barriers to Online Learning."

73 Nancy Hollins and Alan R. Foley, "The Experiences of Students with Learning Disabilities in a Higher Education Virtual Campus." 
assistance to be able to access the learning material. In the common situation, navigating lectures and materials for students with disabilities in UIN Sunan Kalijaga is carried out with the assistance of services provided by PLD, either through staff or volunteers. The absence of PLD services therefore hampering the navigation of the learning process. For Deaf students with limited vocabularies, the absence of a sign language interpreter prevents them from understanding complex academic terminologies.

Still related to support and assistance, online learning certainly cannot be separated from face-to-face instruction. The interaction between lecturers and students, the learning strategy and the attitudes and awareness of lecturer on the needs of students with disabilities in face-to-face class is reflecting in online learning. This confirms the research of Sachs and Scheurer and Robets74 assessment that the awareness and behavior of lecturers and other staff are very important in online learning for students with disabilities. To put it more clearly, inclusive practices and culture in learning are important keys in both online and face-to-face learning systems. The understanding and awareness of lecturers related to disability and inclusive learning have the same role both in the context of online and face-to-face learning systems.

\section{Conclusion}

The online learning system imposed at UIN Sunan Kalijaga - and also other universities in Indonesia-must be seen as an effort to respond to a disaster emergency and not an online learning mechanism that was deliberately built by

74 Robert Connor Chick et al., "Using Technology to Maintain the Education of Residents During the COVID-19 Pandemic." 
considering the general principles that must be present in online learning or ODL.

Given the fact online learning is an effective solution to widen the participation and access to higher education to traditionally dematiaceous group including disabilities, the online learning process during the COVID-19 Pandemic period provide universities, lecturers, and all education practitioners to seriously start working on technology and preparing better infrastructure and resources for ODL mechanism. Specifically related to students with disabilities, the immense agenda of the university and PLD is to build technology that is accessible for students with disabilities, both for online and face-to-face learning.

\section{References}

Ali, Raian, Carlos Solis, Inah Omoronyia, Mazeiar Salehie, and Bashar Nuseibeh. "Social Adaptation: When Software Gives Users a Voice." Wroclaw, Poland, 2012. http://www.enase.org/?y=2012.

Andi, April 17, 2020.

Andrew I. Hashey, and Skip Stahl. "Making Online Learning Accessible for Students With Disabilities:" TEACHING Exceptional Children 45, no. 5 (April 11, 2014): 70-78. https://doi.org/10.1177/0040059914528329. Anton, April 27, 2020. Beti, April 26, 2020.

Chambers Dianne, Varoglu Zeynep, and Kasinskaite-Buddeberg Irmgarda. Learning for All: Guidelines on the Inclusion of Learners with Disabilities in Open and Distance Learning. France: UNESCO Publishing, 2016.

Chenghu Zhou, Fenzhen Su, Tao Pei, An Zhang, Yunyan Du,

Bin Luo, Zhidong Cao, et al. "COVID-19: Challenges to GIS with Big Data." Geography and Sustainability 1, no. 1 
(March

1, 2020):

https://doi.org/10.1016/j.geosus.2020.03.005.

$77-87$.

Chick, R C, G T Clifton, K M Peace, B W Propper, D F Hale, A A Alseidi, and $T$ J Vreeland. "Using Technology to Maintain the Education of Residents During the COVID-19 Pandemic." J Surg Educ, 2020. https://doi.org/10.1016/j.jsurg.2020.03.018.

Christopher Hill, and William Lawton. "Universities, the Digital Divide and Global Inequality." Journal of Higher Education Policy and Management 40, no. 6 (November 2, 2018): $598-610$. https://doi.org/10.1080/1360080X.2018.1531211.

Christy G. Keeler, and Mark Horney. "Online Course Designs: Are Special Needs Being Met?" American Journal of Distance Education 21, no. 2 (June 15, 2007): 61-75. https://doi.org/10.1080/08923640701298985.

Cindy Davi. "There to Stay: Remote Learning Is Poised to Remain a Prominent Fixture of Higher Education." News. systemscontractor, 2020.

https://www.avnetwork.com/features/bus-learning-techteam-discusses-their-move-to-virtual-classrooms.

Danna Harvey, Diana Greer, James Basham, and Bo Hu. "From the Student Perspective: Experiences of Middle and High School Students in Online Learning." American Journal of Distance Education 28, no. 1 (January 2, 2014): 14-26. https://doi.org/10.1080/08923647.2014.868739.

David Alexander. "Disability and Disaster." In Handbook of Hazards and Disaster Risk Reduction, edited by Ben Wisner, Ilan Kelman, and JC Gaillard. New York: Routledge, 2012.

Dini, April 18, 2020.

Dr Debanjan Banerjee. "Psychological Preparedness for the COVID-19 Pandemic, Perspectives from India." Psychiatry Research 288 (June 2020): 112999. https://doi.org/10.1016/j.psychres.2020.112999. 
Fichten, Catherine S., Vittoria Ferraro, Jennison V. Asuncion, Caroline Chwojka, Maria Barile, Mai N. Nguyen, Ryan Klomp, and Joan Wolforth. "Disabilities and E-Learning Problems and Solutions: An Exploratory Study." Educational Technology \& Society 12, no. 4 (2009): 24156.

Francisco Jonathan de Oliveira Araújo, Ligia Samara Abrantes de Lima, Pedro Ivo Martins Cidade, Camila Bezerra Nobre, and Modesto Leite Rolim Neto. "Impact Of Sars-Cov-2 And Its Reverberation In Global Higher Education And Mental Health." Psychiatry Research 288 (April 12, 2020): 112977. https://doi.org/10.1016/j.psychres.2020.112977.

Gay J Mc Dougall. "World Disasters Report 2007 : Focus on

Discrimination." Report Book. World Disaster 2007.

Geneva, CH: Internasional Federation of Red Cross and Crescent Societies, 2007. https://www.ifrc.org/en/publications-and-reports/worlddisasters-report/wdr2007/.

Gewin, Virginia. "Five Tips for Moving Teaching Online as COVID-19 Takes Hold." Nature 580, no. 7802 (March 24, 2020): 295-96. https://doi.org/10.1038/d41586-020-008967.

Guanghai Wang, Yunting Zhang, Jin Zhao, Jun Zhang, and Fan Jiang. "Mitigate the Effects of Home Confinement on Children During the COVID-19 Outbreak." The Lancet 395, no. 10228 (March 21, 2020): 945-47. https://doi.org/10.1016/S0140-6736(20)30547-X.

Heini Utunen, Ngouille Ndiaye, Corentin Piroux, Richelle George, Melissa Attias, and Gaya Gamhewage. "Global Reach of an Online COVID-19 Course in Multiple Languages on OpenWHO in the First Quarter of 2020: Analysis of Platform Use Data." Journal of Medical Internet Research 22, no. 4 (27 2020): e19076. https://doi.org/10.2196/19076.

Herbert Jaeger. "The'"Echo State"'Approach to Analysing and Training Recurrent Neural Networks.” Paper Working. 
Fraunhofer Institute for Autonomous Intelligent System. German: German Nasional research Center For Information Technology, 2010.

Hiba Hafiz, Shu-Yi Oei, Diane M. Ring, and Natalya Shnitser. "Regulating in Pandemic: Evaluating Economic and Financial Policy Responses to the Coronavirus Crisis." SSRN Scholarly Paper. Update To Include Discussion of H.R. Rochester, NY: Social Science Research Network Boston Collage Law School., March 17, 2020. https://doi.org/10.2139/ssrn.3555980.

Jack R Fraenkel, and Norman E Wallen. How to Design and Evaluate Research In Education. New York: McGraw Hill, 2003.

Jaime Saavedra. "Educational Challenges and Oportunities of the Coronavirus (COVID-19) Pandemic." Opini. Published on Education for Global Development, March 30, 2020. https://blogs.worldbank.org/education/educationalchallenges-and-opportunities-covid-19-pandemic.

Jake Bryant, Li-Kai Chen, Emma Dorn, and Stephen Hall. "School-System Priorities in the Age of Coronavirus." Opini. K-12 Education and the Coronavirus, April 21, 2020. https://www.mckinsey.com/industries/public-sector/ourinsights/school-system-priorities-in-the-age-of-coronavirus.

Jan Hollpway, and Chris Foley. "Pros, Cons of Online Education for Students With Disabilities Be Sure Consider Technical and Personal Needs Befor Diving Into Online Learning." Opini. Education, May 18, 2018. https://www.usnews.com/education/online-learninglessons/articles/2018-05-18/pros-cons-of-online-educationfor-students-with-disabilities.

Jianxia Du, Byron Havard, and Heng Li. "Dynamic Online Discussion: Task-oriented Interaction for Deep Learning." Educational Media International 42, no. 3 (September 1, 2005): 207-18. https://doi.org/10.1080/09523980500161221. 
Jodi B. Roberts, Laura A. Crittenden, and Jason C. Crittenden. "Students with Disabilities and Online Learning: A CrossInstitutional Study of Perceived Satisfaction with Accessibility Compliance and Services." The Internet and Higher Education 14, no. 4 (September 1, 2011): 242-50. https://doi.org/10.1016/j.iheduc.2011.05.004.

Kaliope Azzi-Huck, and Tigran Shmis. "Managing the Impact of COVID-19 on Education Systems Around the World: How Countries Are Preparing, Poping, and Planning for Recovery." Opini. Published on Education for Global Development, March $18,2020$. https://blogs.worldbank.org/education/managing-impactcovid-19-education-systems-around-world-how-countriesare-preparing.

Karen Kear, Allan Jones, Georgina Holden, and Mark Curcher. "Social Technologies for Online Learning: Theoretical and Contextual Issues." Open Learning: The Journal of Open, Distance and e-Learning 31, no. 1 (January 2, 2016): 42 53. https://doi.org/10.1080/02680513.2016.1140570.

Lendel Narine, and Cristian Meier. "Responding In a Time of Crisis: Assessing Extension Efforts During COVID-19." Advancements in Agricultural Development 1, no. 2 (April 17, 2020): 12-23. https://doi.org/10.37433/aad.vli2.35.

Lin Y. Muilenburg, and Zane L. Berge. "Student Barriers to Online Learning: A Factor Analytic Study." Distance Education 26, no. 1 (January 1, 2005): 29-48. https://doi.org/10.1080/01587910500081269.

Lorrayne Porciuncula, and Sam Paltridge. "Bridging the Rural Digital Divide." OECD Digiatal Economy Paper, no. 265 (February 23, 2018): 1-71. https://doi.org/10.1787/852bd3b9-en.

Maria Nicola, Zaid Alsafi, Catrin Sohrabi, Ahmed Kerwan, Ahmed Al-Jabir, Christos Iosifidis, Maliha Agha, and Riaz Agha. "The Socio-Economic Implications of the Coronavirus and COVID-19 Pandemic: A Review." 
International Journal of Surgery (London, England), April 17, 2020. https://doi.org/10.1016/j.ijsu.2020.04.018.

Mark Warschauer, and Tina Matuchniak. "New Technology and

Digital Worlds: Analyzing Evidence of Equity in Access, Use, and Outcomes:" Review of Research in Education 34, no. 1 (March 2010). https://doi.org/10.3102/0091732X09349791.

Mary F. Rice, and Bryan Dykman. "The Emerging Research Base on Online Learning and Students with Disabilities." In Handbook of Research on K-12 Online and Blended Learning, edited by Richard E. Ferdig and Kathryn Kennedy. Pittsburgh, PA: Carnegie Mellon University, 2018. https://doi.org/10.1184/R1/6686813.v1.

Nalini Pather, Phil Blyth, Jamie A. Chapman, Manisha R. Dayal, Natasha A. M. S. Flack, Quentin A. Fogg, Rodney A. Green, et al. "Forced Disruption of Anatomy Education in Australia and New Zealand: An Acute Response to the Covid-19 Pandemic." Anatomical Sciences Education, 2020, 1-14. https://doi.org/10.1002/ase.1968.

Nancy Hollins, and Alan R. Foley. "The Experiences of Students with Learning Disabilities in a Higher Education Virtual Campus." Educational Technology Research and Development 61, no. 4 (August 1, 2013): 607-24. https://doi.org/10.1007/s11423-013-9302-9.

Neil Selwyn, and Keri Facer. "The Sociology of Education and Digital Technology: Past, Present and Future." Oxford Review of Education 40, no. 4 (July 4, 2014): 482-96. https://doi.org/10.1080/03054985.2014.933005.

Nina, April 18, 2020.

Nisa, April 16, 2020.

Paxson, Christina. "College Campuses Must Reopen in the Fall. Here's How We Do It." The New York Times. April 26, 2020, sec. Opinion. https://www.nytimes.com/2020/04/26/opinion/coronaviruscolleges-universities.html. 
Rachel Grieve, Michaelle Indian, Kate Witteveen, G. Anne Tolan, and Jessica Marrington. "Face-to-Face or Facebook: Can Social Connectedness Be Derived Online?" Computers in Human Behavior 29, no. 3 (May 1, 2013): 604-9. https://doi.org/10.1016/j.chb.2012.11.017.

Rani, April 16, 2020.

Reno, April 17, 2020.

Ridho, April 15, 2020. , April 21, 2020.

\section{$\longrightarrow$, April 29, 2020.}

Robert Connor Chick, Guy Travis Clifton, Kaitlin M. Peace, Brandon W. Propper, Diane F. Hale, Adnan A. Alseidi, and Timothy J. Vreeland. "Using Technology to Maintain the Education of Residents During the COVID-19 Pandemic." Journal of Surgical Education, April 3, 2020. https://doi.org/10.1016/j.jsurg.2020.03.018.

Sandara, April 15, 2020.

Sarah Wood. "How Colleges Can Support Students With Disabilities During Remote Learning." News. Diverse Issues In Higher Education, April 13, 2020. https://diverseeducation.com/article/172812/.

Taha, Mohamed H., Mohamed Elhassan Abdalla, Majed Wadi, and Husameldin Khalafalla. "Curriculum Delivery in Medical Education during an Emergency: A Guide Based on the Responses to the COVID-19 Pandemic." MedEdPublish 9, no. 1 (April 16, 2020): 1-12. https://doi.org/10.15694/mep.2020.000069.1.

Theopania Chavatzia, and Megumi Watanabe. "Preparing The Reopening of Schools." Resource Paper. Education Covid19 Response. Ajuba, Bangkok, Beijing, Hanoi, Mexico, and Santiago: UNESCO International Institute For Educational Planning (IIEP), $\quad$ May 2020. https://unesdoc.unesco.org/ark:/48223/pf0000373401.

Timothy Morse. "Ensuring Equality of Educational Opportunity in the Digital Age." Education and Urban Society 36 (May 
$38 \mid$ Ro'fah, at.all

1 , 2004):

266-79.

https://doi.org/10.1177/0013124504264103.

William E. Halal. "The Power of Online Learning Systems." Opini. The Future of The Future, 2006. https://www.kmworld.com/Articles/Columns/The-Futureof-the-Future/The-Future-of-the-Future-The-power-ofonline-learning-systems-16909.aspx.

Y. Yuliana. "Corona virus diseases (Covid-19): Sebuah tinjauan literatur." Wellness And Healthy Magazine 2, no. 1 (March 6, 2020): 187-192-192.

Zhang, Wunong, Yuxin Wang, Lili Yang, and Chuanyi Wang. "Suspending Classes Without Stopping Learning: China's Education Emergency Management Policy in the COVID19 Outbreak." Journal of Risk and Financial Management 13, no. 3 (March 2020): 55. https://doi.org/10.3390/jrfm13030055. 